Bocoli, F.A.; Marcon J.A.; Izidoro, M.; Bortolon, P.T; Oliveira S.E.R.; Spalevic, V; Souza, P.S. (2020): Bokashi use in the Passionfruit (Passiflora edulis L.) germination and initial growth. Agriculture and Forestry, 66 (4): 101-111.

DOI: 10.17707/AgricultForest.66.4.08

Fernanda Almeida BÓCOLI ${ }^{1}$, Jaqueline Aparecida MARCON ${ }^{2}$, Maiqui IZIDORO ${ }^{2}$, Pedro de Toledo BORTOLON ${ }^{3}$, Sérgio Emílio Rodrigues de OLIVEIRA ${ }^{3}$, Velibor SPALEVIC ${ }^{4}$, Paulo Sérgio de SOUZA ${ }^{3}$

\title{
BOKASHI USE IN THE PASSIONFRUIT (Passiflora edulis L.) GERMINATION AND INITIAL GROWTH
}

\section{SUMMARY}

The passionfruit has high relevance to Brazilian fruticulture, widely used in the food business. Its seedlings production, might attempt to the utilized substrate characteristics, its organic matter content, adequate nutrients concentration, good aeration, and pathogens agents' absence. Nowadays is increasing the use of renewable fertilizers in detriment to mineral ones, such as the bokashi and the organics compost in agriculture, although few studies are made to test how it affects different plants' metabolism. Due to this circumstance, more studies must test its effectiveness. The bokashi possesses several favourable characteristics as nutrients rapid release, soil structure maintenance, some pests, and disease prevention and control. This study used the bran rice bokashi and the organic compost aiming to verify its effect on passionfruit seedlings germination and initial growth in the tube at the greenhouse. The study area was in the fruticulture sector, on the Instituto Federal de Educação, Ciência e Tecnologia do Sul de Minas Gerais (IFSULDEMINAS), Muzambinho Campus, Brazil. The treatments were different bran rice bokashi doses with organic compost: T1 $(0 \% / 100 \%$, respectively bokashi/organic compost), T2 (2\%/98\%), T3 (4\%/96\%), T4 $(8 \% / 92 \%)$, T5 (16\%/84\%) and T6 (32\%/68\%). The adopted outline was the RBD, six treatments, and four repetitions, and eight tubes per portion. The obtained data submitted to statistical analysis, the treatments that stood out regarding the germination, were mainly the witness T1, T3, and T5. About the plants' growth treatments T4, T5, and T6; the T5 was the best treatment due to the high seeds germination and plant development rate on this experiment conditions.

Keywords: Alternative Substrates; Organic fertilizers; Seedlings production; Sustainable agriculture.

\footnotetext{
1 Fernanda Almeida Bócoli (corresponding author: bocolifernanda@gmail.com), Universidade Federal de Lavras, Lavras, Minas Gerais, BRAZIL.

${ }^{2}$ Jaqueline Aparecida Marcon, Maiqui Izodoro, Universidade Estadual Paulista, Butucatu, BRAZIL.

${ }^{3}$ Pedro de Toledo Bortolon, Sérgio Emílio Rodrigues de Oliveira, Paulo Sérgio de Souza, Instituto Federal de Educação Ciência e Tecnologia do Sul de Minas Gerais, Muzambinho, BRAZIL.

${ }^{4}$ Velibor Spalevic, University of Montenegro, Faculty of Philosophy, Geography, Niksic, MONTENEGRO.

Notes: The authors declare that they have no conflicts of interest. Authorship Form signed online.
} 


\section{INTRODUCTION}

The passion fruit (Passiflora edulis L.) has as its birthplace tropical America and high relevance to the Brazilian fruticulture, once Brazil is the largest sour passionfruit producer and consumer in the world, being its fruits utilized as much to juice, sweet and sauces production as in natural consumption. Since this is a fruit culture in highlight into the national market, it very important to attempt on all cultivation aspects, from cultivar choose, seedlings production, crop handling until its harvest and commercialization, to thereby being optimized its production chain procedures. Although the passion fruit has a high capacity for a great production, the country presents low productivity compared to other producers in the world (Embrapa, 2016).

Silanaj et al. (2012) highlight that great fruit production depends on the seedling's quality, which is a result of the culture propagation methods. The most used technique for the passion fruit is per seed, due to its precocity in floral buttons production, which starts this process three to four months after its planting (Melo; Tavares, 2001). For being more advantageous, this method is the most applied by the fruit growers to the passion fruit seedlings production.

According to Melo and Tavares (2001), to a good passion fruit seedlings production, it must have to attempt to the utilized substrate characteristics, being important its organic matter content, adequate nutrients concentration, and good aeration, besides being pathogenic agents free. However, the commercial substrates generally do not provide organic sources mostly, beyond being costly to the producer. Thus, it is indispensable the creation and test of new quality and unexpansive mechanisms to seedlings production.

Nowadays we are recording increasing of the studies that are using alternative fertilizers such as the bokashi and organic compost in agriculture (Lense et al. 2020; Goelzer et al. 2019; Santos et al., 2019; Pinto, 2018; Silva, 2016; Jaramillo-López et al., 2015; Blecic et al., 2014; Sorace, 2011; Cavalcante, 2010; Hafle et al., 2009;). Although the bokashi use in tropical fruits as the passion fruit it is not something so explored in the literature.

The composts are alternative fertilizers, providing several advantages since they are biodegradable, generally result from plants and animals remain. They promote the soil nutrients cycling, the O.M. increase (Karimuna et al., 2016), and a favorable environment to biological agents that has pests and disease controlaction. Moreover, a healthy environment generates healthy individuals, as in the trophobiosis theory (Rivera, 2014).

The bokashi is an organic fertilizer prepared from the fermentation promoted by the bacteria and other organisms found in an inoculant, the Effective Microorganisms - EM (Jaramillo-López et al., 2015). Other elements can compound this fertilizer as wheat, rice, and corn bran, enriched with bones flour and animal manure as for poultry, being the bran most rich in nitrogen (Pinto, 2018). This composition varies according to the culture necessity and also with the available materials in the property (Jaramillo-López et al., 2015; Rivera, 2014). 
Yamada and Xu (2001) and Jaramillo-López et al. (2015), stand out greatly properties found out on fermented organic fertilizers that incremental EM, as the presence of soil and plants benefit organism, highlights the Lactobacillus spp. and the Actinomycetes, beyond nutrients and organic composts as aminoacidic, organic acids, macro, and micronutrients in small percentages. The authors also emphasize the organic fertilizer quality depends on initial preparation water quantity, organic carbon supply, and energy sources, besides the microbiological inoculant utilized.

When comparing nutrients sources, mineral fertilizing has as the advantage of its concentration, which is larger than the organic. Now the organic, according to Cavalcante (2010) and Jaramillo-López et al. (2015), possess as main advantages the soil structure maintenance, nutrients balanced release, supply charges for soil cationic exchange capacity (CEC) and organic matter (O.M.) incorporation, predators' microorganisms of pests and plant disease causal agents, besides supporting the root growth.

Another point that favors the organic sources' use is the mineral fertilizes rise price, due to this product importation and the constant dollar appreciation against the real, the unit of currency in Brazil. With organic sources utilization to the fertilizers and subtracts production to the property, the producer will have more profitability on final product sale, already his production costs will reduce, and he can use his property residues or from an agribusiness having the input with a reduced value, besides the environmental coverage, ruled in the organic residues reuse and recycling (Jaramillo-López et al., 2015; Pinto, 2018). Popovic et al. (2020), for example, had as the objective of their study, in Podgorica vineyard region; the mineral fertilizers reduce use, substituting part of them by organic sources. They obtained good results for grape production, improving the use of mineral fertilizers and reducing the chance of environmental pollution from excessive utilization.

According to Ishimura (2004), the bokashi possess several favorable characteristics on the agriculture, once afford rapid nutrients release, assists on soil physics aspects, as its structure maintenance, besides also support in some diseases and pest's prevention and control, once it has a microorganism's broad range, introduced with the EM utilization, prepared from organism's virgin forest collected.

The passionfruit producers have a strong need to obtain low-cost seedlings than the alternative substrates use with security phytosanitary characteristics become essential. We aimed to study the bran rice bokashi effect in the passionfruit seedlings' germination and initial development from seeding to the point to send to the field in greenhouse conditions.

\section{MATERIAL AND METHODS}

The experiment was greenhouse conduced at Instituto Federal de Educação Ciência e Tecnologia do Sul de Minas Gerais, fruticulture sector, Muzambinho 
campus, Brazil, whose coordinates are, latitude: $21^{\circ} 20^{\prime} 59,94^{\prime}$ 'S and longitude: 46 31'34,82' 'W, with 1013 meters of mean altitude (Aparecido et al., 2014).

The bokashi's treatment doses were adapted from Silva (2016) and Manoel et al. (2005) studies. The fruticulture sector produced the bokashi and substrate compounds. The bokashi obtained from two liters of EM ( 0.2 liters of concentrate $\mathrm{EM}+0.2$ liters of cane molasses +1.6 liters of water without chlorine) added to 20 liters of bran rice and closed packed conditioned to its anaerobic production. The substrate was an organic compost, originated from leaves, and grasses remain with bovine manure, to achieve the relation $\mathrm{C} / \mathrm{N}$ equal to $30 / 1$, aerobically composted, after sifted, and added $20 \%$ in volume of wood shavings, thereon, steam-treated at $100^{\circ} \mathrm{C}$ by at least one hour, for the substrate be out of pathogen agents.

The utilized seeds were obtained from commercial fruits, put to dry in the shade on environmental temperature per 24 hours into an absorbent paper to take off all the moisture and its mucilage. The seeds were selected and planted two to each tube. The selection takes on account the mature seeds that present a darker color and the larger ones because they have the largest nutrients reserves for their initial development.

The randomized block design (RBD) was the used one, with six treatments. The percentages utilized were detailed in Table 1, divided into four blocks at random, and each portion with eight tubes of $120 \mathrm{~cm}^{3}$.

The Bokashi handoff by previous sifting hereafter weighed and measured the volumes of the Bokashi and the substrate. After the density of each compound verified, were established the proportions to compose the treatments in percentages (Table 1).

Table 1: Treatments adopted in the present work in percentages combining the substrate and the barn rice bokashi. IFSULDEMINAS, Muzambinho municipality, Minas Gerais state, Brazil 2019.

\begin{tabular}{lll}
\hline Treatments & Bokashi & Substrate \\
\hline T1 & $0 \%$ & $100 \%$ \\
T2 & $2 \%$ & $98 \%$ \\
T3 & $4 \%$ & $96 \%$ \\
T4 & $8 \%$ & $92 \%$ \\
T5 & $16 \%$ & $84 \%$ \\
T6 & $32 \%$ & $68 \%$ \\
\hline
\end{tabular}

The watering was daily having the care of use water without chlorine to have no interference in the microorganism's population presents in the bokashi and consequently in the substrate, once that sought to verify their action in the seedling's emergence and initial growth. The seedlings thinning was realized 
when they were with about 0,05 to 0,08 meters high, leaving only the more vigorous seedlings on each tube.

The realized phytometric evaluations were emerged seedlings number evaluated weekly, count until its population stabilization, being the count initialized fifteen days after the seeding (DAS), and the seedlings high measurement, from 45 DAS were realized weekly measurements until 60 DAS, being considered as useful installment the five marked central seedlings. In the emerged seedlings count was taken into account that each tube has just one seedling.
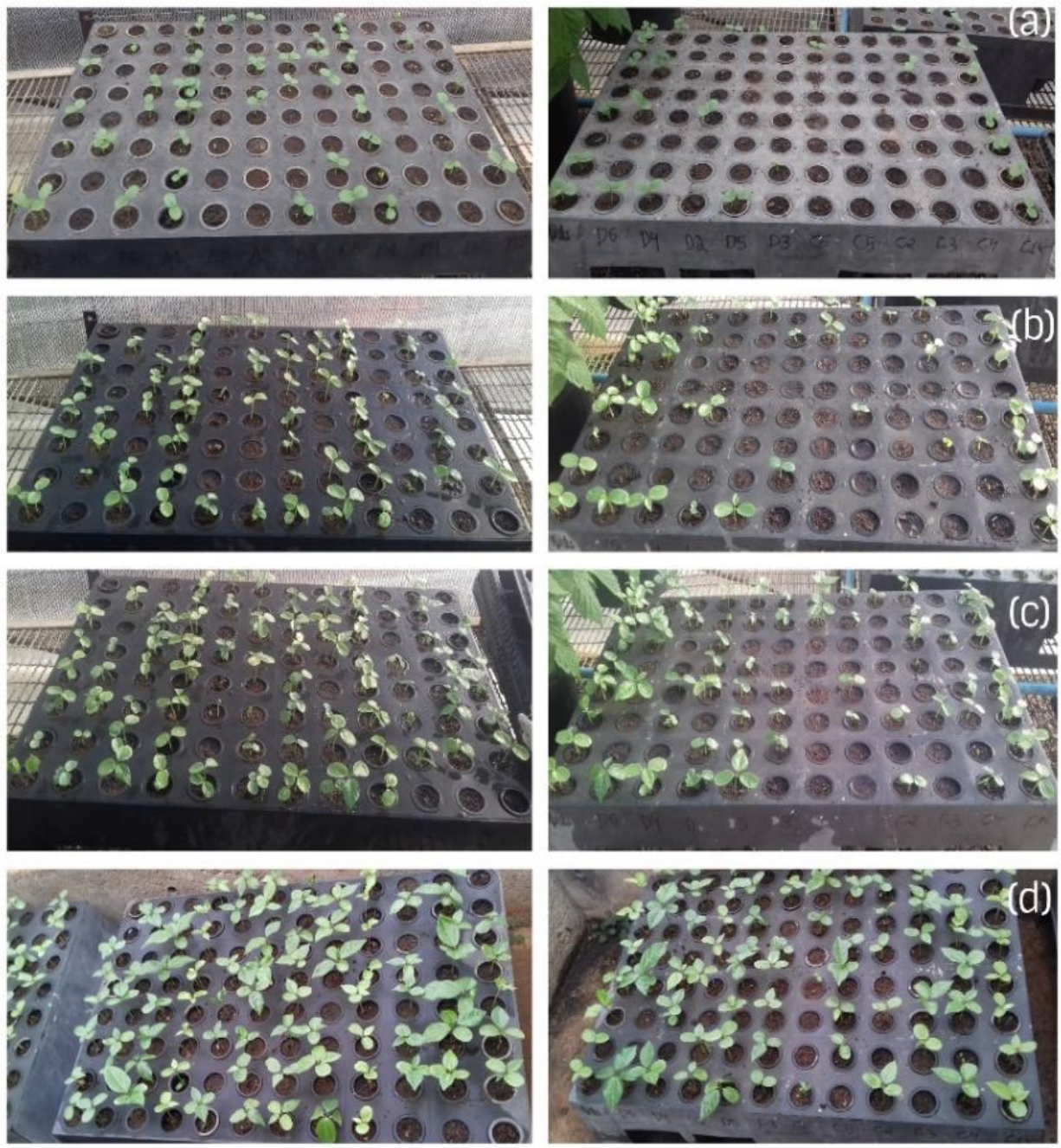

Figure 1a: Passionfruit germination and initial growth in barn rice bokashi and organic compost on each evaluation day. IFSULDEMINAS, Muzambinho municipality, Brazil. 


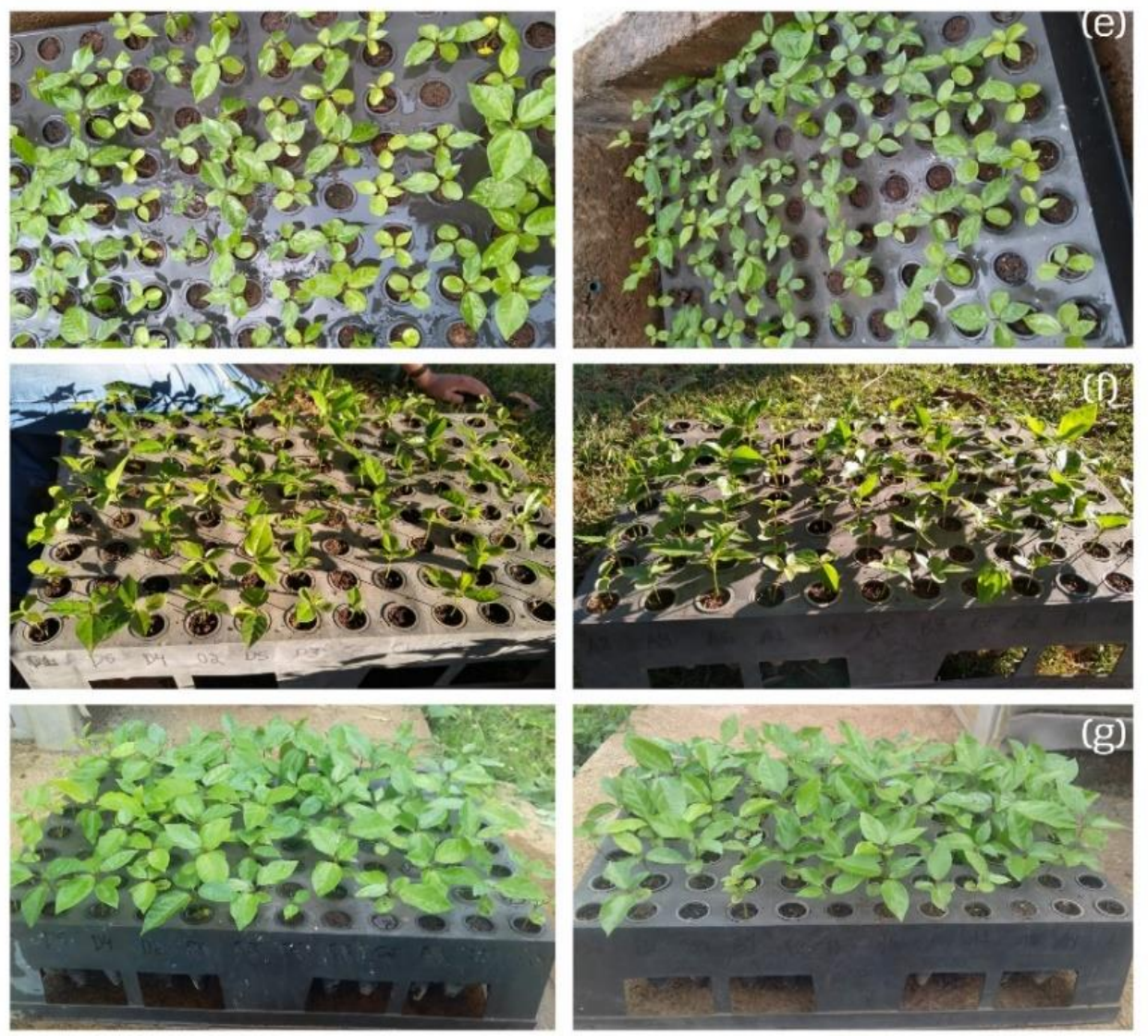

Figure 1b: Passionfruit germination and initial growth in barn rice bokashi and organic compost on each evaluation day. IFSULDEMINAS, Muzambinho municipality, Brazil.

*(a) 15 DAS; (b) 21 DAS; (c) 28 DAS; (d) 35 DAS; (e) 42 DAS; (f) 49 DAS; (g) 56 DAS.

For the statistical analyses, the germination data transformed into percentages. There was no need for pests and disease control once there was no incidence in the passionfruit seedlings during the experiment.

The Tukey and statistical analysis of variance (ANOVA) test were employed to analyze the response variables at a $5 \%$ of probability through the statistical software R (R Core Team, 2020).

\section{RESULTS AND DISCUSSION}

As for the parameter emerged seedlings percentage, the $\mathrm{T} 1$ was superior to all other treatments on 21 DAS, meantime on 42 DAS, the treatments T3 and T5 do not differ statically of T1. The hypothesis is that the action of the bokashi microorganisms initially utilizes the nutrients, and only after slowly is release them to the plants, which differs from when it is only the substrate, so the seeds 
that first emerged were the witness treatment (Figure 2). Such a hypothesis corroborated in Figure 3 that is self-evident on 60 DAS T4, T5, and T6 show themselves more efficient regarding the growing than the other treatments, probably the moment where that these nutrients are readily available to the seedling emerged absorb and grow.
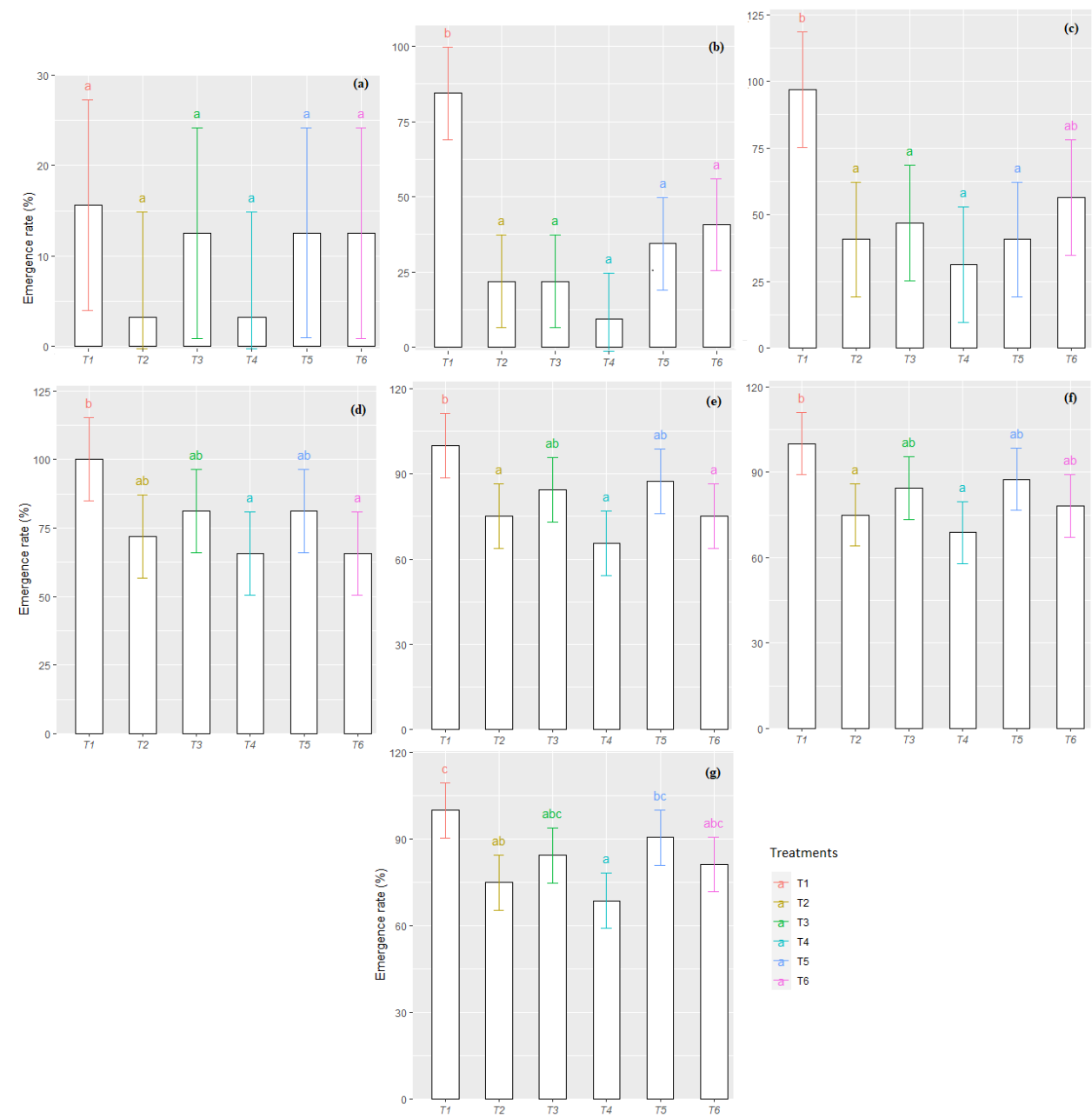

(g)

Figure 2: Passionfruit seedling's germination mean percentages and its respective treatment. IFSULDEMINAS, Muzambinho municipality, Minas Gerais state, Brazil, 2019.

Means followed by the same letter in the vertical has no difference among each other in the Tukey statistical test at 5\% of significance. (a) 15 Days After Seeding (DAS); (b) 21 DAS; (c) 28 DAS; (d) 35 DAS; (e) 42 DAS; (f) 49 DAS; (g) 56 DAS. 
In Santos et al. (2019) study, the bokashi increasing doses used in the substrate for the transplant of Campomanesia adamantium (Cambess.) O. Berg, a Cerrado Myrtaceae native fruit, was observed that the mortality could reach $100 \%$ of the seedlings when the bokashi content increased until the dose $20 \mathrm{~g} \mathrm{~kg}^{-1}$ of soil. In the case of this study of initial growth, was observed that the seeds in the substrate with bokashi took longer time to germinate, while the standard substrate had a greater germination index (Figure 2). Differently from what was observed by Santos et al. (2019), the used doses at the experiment do not cause passionfruit seedling death.

When in the first 28 DAS was observed that one of the treatments that added bokashi equalize the emergency to the witness but yet not differ from the other treatments. On the following evaluation days, the same response has been found in the bokashi treatments not being superior then the witness in any of them. Although this fact, we saw a tendency for treatments T5 to have greatest results for differing from the treatments with lower germination rates.

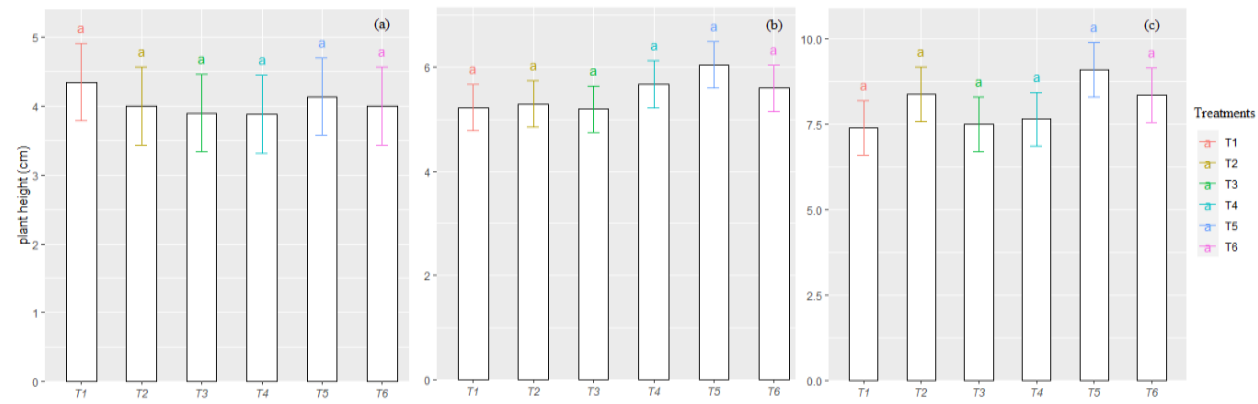

Figure 3: Passionfruit seedling's height mean values and its respective treatment. IFSULDEMINAS, Muzambinho municipality, Minas Gerais state, Brazil, 2019.

Means followed by the same letter in the vertical has no difference among each other in the Tukey statistical test at $5 \%$ of significance. (a) 45 Days After Seeding (DAS); (b) 53 DAS; (c) 60 DAS.

When performed the ANOVA test for plant height on 45 days after seeding, there is no difference among the treatments. In 53 and 60 DAS, the T5 (p value $<0.05 ; 0.0135$ and 0.00527 respectively) was superior to the other treatments when compared to the witness. Jaramillo-López et al. (2015), in their study of impacts of Bokashi on survival and growth rates of Pinus pseudostrobus in community reforestation in Mexico, found out that the trees that received Bokashi were significantly taller than those that not, what occurred here too. Another positive effect that Jaramillo-López et al. (2015) found is that the survival rate of the seedlings increased. SILVA et al. (2018), also observed greater values to plant height in the beet culture when added bokashi.

Although the ANOVA test pointed out the best treatment for the T5, in the Tukey test analysis, no difference reached out, regardless of the day (Figure 3). 
Sorace (2011), at her alternative substrates to the potted chrysanthemum culture study, declares that the use of substrates with mineral fertilizers added to bokashi or humus increases the culture vegetative and the reproductive development, beyond the bokashi be better than the hummus since enhancing the inflorescences number. When we compare this study to the data obtained from this work, we can verify a tendency that the treatments that added bokashi present better results concerning its growing, mostly on 53 and 60 DAS the ANOVA test indicated that the T5 had the best response in improving seedling's growth in comparison to the witness. Similar to what Oladele (2015) studies found, higher and vigorous plants, possibly because of the aid of nutrients uptake and water acquisition, in Akure Ondo State, Nigeria. The author inoculated arbuscular mycorrhizal fungi (Glomus mossae) on cacao (Theobroma cacao) seedlings. These arbuscular mycorrhizal fungi can be found on the EM to bokashi production because they live in virgin forests and almost all soils.

Hafle et al. (2009), on his papaya seedlings production study, observed that the bokashi at 60 DAS jointly with the seaweed powder (lithothamnium), had a significate effect as for the aerial part growth, the length had an upward linear growth according to the bokashi percentage increment into the substrate from 0 to $10 \%$. The same relation observed in this present study on ANOVA test, that the superior bokashi doses afforded passionfruit seedlings higher aerial part growth when at 53 and $60 \mathrm{DAS}$, then the best treatment to this parameter is T5.

Manoel et al. (2005) on his different substrates to Arabic coffee cultivar Obatã (Coffea arabica cv. Obatã) seedlings study obtained the greater height values to the treatments with bokashi higher contents (10\%), produced by anaerobic form, intermediate values (5\%), from aerobic bokashi production, and with the bovine manure added to conventional fertilizer. Although no significant difference has been found from the other percentages of substrates with bokashi, the treatments with organic sources achieved the best performance. In this study, we obtained significative differences among the seedlings at 53 and 60 DAS on ANOVA test, when it is used the larger bokashi percentages in the treatments T5 (16\% of bokashi), differing statistically from T1, T2, T3, T4 and T6 (0, 2, 4, 8 and $32 \%$ of bokashi).

Goelzer et al. (2019), studying the Campomanesia adamantium (Cambess.) O. Berg initial growth observed that the Fertbokashi ${ }^{\circledR}$ influences positively in the stem dry matter having its maximum point next of $0,5 \mathrm{~L} \mathrm{ha}^{-1}$, also demonstrates itself positive in the relation between aerial part and radicular dry material tending to a positive linear function. Nonetheless, the applied Fertbokashi ${ }^{\circledR}$ doses barely influenced the guavira initial growth. However, in the present experiment, corroborate in parts on what found out in their study, we have observed significative influences in the initial growth fruitful tree here aborded, differing from the other treatments at 53 and 60 DAS by ANOVA test at $5 \%$ of significance. Karimuna et al. (2016) observed on their study that the bokashi improved the agronomic characteristics of peanut and maize in nutrient poor soils 
in Indonesia demonstrating a potential use of this natural fertilizer in other cultures too.

\section{CONCLUSIONS}

The treatments that stood out for the germination were the witness (T1), in the beginning, and posteriorly the T3, T5 and the T6 equalized to the witness, however only the T5 did not demonstrate equivalence to the treatments with low germination percentages.

As for the plants growing, the treatment T5 were superiors to the others at 53 and 60 DAS in ANOVA test $(\mathrm{p}<0.05)$, meanwhile at Tukey statistical test at $5 \%$ of significance has no difference among the treatments.

The treatment T5 (16\% Bokashi) was the one whose passionfruit seedlings growing were significatively greater on ANOVA test. Thus, this would be a treatment recommended to a seedling passionfruit grower.

\section{ACKNOWLEDGEMENTS}

The authors thank the Instituto Federal de Educação, Ciência e Tecnologia do Sul de Minas Gerais for the installations, materials and equipment availability to the present research operation. The first author is grateful for receiving the support for the scholarship from the foment study institution CNPq, jointly the CAPES and FAPEMIG.

\section{REFERENCES}

Aparecido, L.E.O. (2014): Estratégia Global e Sistemas Produtivos Brasileiros Análise Climática para a Região de Muzambinho MG. In: IX Workshop de Pós-graduação e Pesquisa do Centro Paula Souza São Paulo Centro Paula Souza. p. 97-104.

Blecic, A.; Railic, B.; Dubljevic, R.; Mitrovic, D.; and Spalevic, V. (2014): Application of Sapropel in agricultural production. Agriculture and Forestry, 60 (2): 243-250.

Cavalcante, I.H.L. (2010): Fertilizantes orgânicos para o cultivo da melancia em Bom Jesus-PI. Revista Brasileira de Ciências Agrárias, Recife, v.5, n.4, p.518-524.

EMBRAPA. Maracujá: o produtor pergunta e a EMBRAPA responde. O produtor pergunta e a EMBRAPA responde. Brasília: Embrapa, 2016. 348 p.

Goelzer, A.; Silva, O.B.; Santos, F.H.M.; Carnevali, T.O.; Zárate, N.A.H.; Vieira, M. C. (2019): Crescimento inicial da Campomanesia adamantium (Cambess.) O. Berg cultivada em diferentes substratos e doses de fertbokashi. Brazilian Applied Science Review, Curitiba, v. 3, n. 4, p.1783-1797. Brazilian Applied Science Review. http://dx.doi.org/10.34115/ basrv3n4-007.

Hafle, O.M.; Santos, V.A.; Ramos, J.D.; Cruz, M.C.M.; Melo, P.C. (2009): Produção de mudas de mamoeiro utilizando Bokashi e Lithothamnium. Revista Brasileira de Fruticultura, v. $31, \quad$ n. 1, p.245-251. FapUNIFESP (SciELO). http://dx.doi.org/10.1590/s0100-29452009000100034.

Ishimura, I (2004): Adubação Orgânica em hortaliças. In: Ishimura I (Ed.) Manual de Agricultura Orgânica. Piracicaba: Jica, p 76-114.

Jaramillo-López, P.F.; Ramírez, M.I.; Pérez-Salicrup, D.R. (2015): Impacts of Bokashi on survival and growth rates of Pinus pseudostrobus in community reforestation projects. Journal of Environmental Management, 150: 48-56. http://dx.doi.org/10.1016/j.jenvman.2014.11.003. 
Karimuna, L.; Rahni, N.M.; Boer, D. (2016): The Use of Bokashi to Enhance Agricultural Productivity of Marginal Soils in Southeast Sulawesi, Indonesia. Journal Of Tropical Crop Science, Sulawesi, 3 (1): 1-6.

Lense, G. H. E., Moreira, R. S., Bócoli, F. A., Parreiras, T. C., Teodoro, A. E. de M., Spalevic, V., Mincato, R. L. (2020): Soil organic matter loss by water erosion in a coffee organic farm. Agriculture and Forestry, 66 (2): 45-50

Manoel, R.M.; Haddad, J.; Truzzi, K.D.C.; Postali, L.G.B.; Takahashi, K.; Pedini, S.; Chagas, P.R.R. (2005): Diferentes substratos para produção de mudas de cafeeiro (Coffea arabica L. cv. Obatã). In: Simpósio de pesquisa dos Cafés do Brasil, 4., 2005, Londrina. Anais. Brasília: Embrapa Café, 2005. p. 1 - 4.

Melo, M.B.; Tavares, E.D. (2001): Maracujá amarelo: Recomendações para produção de mudas. Aracaju: Embrapa Tabuleiros Costeiros, 2001. 27 p.

Oladele, S. (2015): Mycorrhizal fungus (Glomus mossae) inoculation effects on performance and root biomass development of cacao seedlings in the nursery. Agriculture and Forestry, 61 (3): 69-76, Podgorica.

Pinto, D.F.P. (2018): Composto bokashi com inóculo nativo e comercial, farinha de penas e a disponibilidade de nitrogênio e fósforo. 2018. 61 f. Dissertação (Mestrado) Curso de Agronomia, Solos e Nutrição de Plantas, USP/ Escola Superior de Agricultura "Luiz de Queiróz", Piracicaba, 2018.

Popovic, T.; Mijovic, S.; Scepanovic, R. P.; Raicevic, D. (2020): Analysis of possibilities of reducing the quantity of mineral fertilizer application using different types of organic fertilizers in cardinal grape variety. Journal Agriculture and Forestry, 66 (1): 261-268, Podgorica. http://dx.doi.org/10.17707/agricultforest.66.1.24.

R Core Team (2020): A language and environment for statistical computing. R Foundation for Statistical Computing, Vienna, Austria. URL https://www.Rproject.org/.

Rivera, J. R. (2014): Manual de Agricultura Orgânica. Atalanta: Org. Dalva Sofia Schuch, 2014. 82 p. Disponível em: <http://www.saude.pr.gov.br/arquivos /File/Manual_AgriCULTURA_ORGANICA_Jairo_Restrepo_Rivera.pdf>. Acesso em: 06 fev. 2020.

Santos, C.C.; Bernardes, R. da S.; A., Goelzer; Geist, M. L.; Vieira, M. do C.; Zárate, N. A. H. (2019): Bokashi em mudas de Campomanesia adamantium (Cambess.) O. Berg: aspectos morfométricos e fotoquímicos. Nativa: Pesquisas Agrárias e Ambientais, Sinop, 7 (3): 239-243.

Silanaj, S.; Fetahu, S.; Vucetaj, S.; Avdiu, V. (2012): The quality of seedlings of different cultivars and rootstocks of apple produced by the "KNIP" method. Agriculture and Forestry, 58 (4): 145-151, Podgorica.

Silva, C.F. (2016): Doses de bokashi no crescimento de duas cultivares de manjericão (Ocimum basilicum L.). 2016. 43 f. TCC (Graduação) - Curso de Agronomia, Centro de Ciências Agrárias, Universidade Federal do Ceará, Fortaleza, 2016.

Silva, P. N. de L.; Lanna, N. de B. L.; Cardoso, A. I. I. (2018): Doses de Bokashi em cobertura na produção de beterraba. Revista de Agricultura Neotropical, Cassilândia, (5) $1: 28-34$.

Sorace, M. (2011): Compostos Orgânicos no Cultivo em Vaso de Crisântemo. 72 f. Tese (Doutorado) - Curso de Programa em Pós-Graduação em Agronomia, Universidade Estadual de Londrina, Londrina, 2011.

Yamada, K.; Xu, H. (2001): Properties and Applications of an Organic Fertilizer Inoculated with Effective Microorganisms. Journal of CropProduction, 3 (1): 255268. http://dx.doi.org/10.1300/j144v03n01_21. 